https://doi.org/10.5194/bg-2022-44

Preprint. Discussion started: 8 March 2022

(c) Author(s) 2022. CC BY 4.0 License.

(c) (i)

\title{
Upwelled plankton community modulates surface bloom succession and nutrient availability in a natural plankton assemblage
}

\author{
Allanah J. Paul ${ }^{1 *}$, Lennart T. Bach ${ }^{2}$, Javier Arístegui ${ }^{3}$, Elisabeth von der Esch ${ }^{1}$, Nauzet Hernández- \\ Hernández $^{3}$, Jonna Piiparinen ${ }^{4}$, Laura Ramajo ${ }^{5,6,7}$, Kristian Spilling ${ }^{4,8}$, Ulf Riebesell ${ }^{1}$ \\ $5 \quad{ }^{1}$ GEOMAR Helmholtz Centre for Ocean Research Kiel, Düsternbrooker Weg 20, 24105 Kiel, Germany \\ ${ }^{2}$ Institute for Marine and Antarctic Studies, University of Tasmania, Hobart, Tasmania, Australia \\ ${ }^{3}$ Instituto de Oceanografía y Cambio Global (IOCAG), Universidad de Las Palmas de Gran Canaria (ULPGC), Las Palmas, \\ Spain \\ ${ }^{4}$ Marine Research Centre, Finnish Environment Institute, Helsinki, Finland \\ $10{ }^{5}$ Center for Advanced Studies in Arid Zones (CEAZA), Coquimbo, Chile \\ ${ }^{6}$ Departamento de Biología Marina, Facultad de Ciencias del Mar, Universidad Católica del Norte (UCN), Coquimbo, Chile \\ ${ }^{7}$ Center for Climate and Resilience Research (CR)2, Santiago, Chile \\ ${ }^{8}$ Centre for Coastal Research, University of Agder, Kristiansand, Norway
}

Correspondence to: Allanah J. Paul (apaul@geomar.de)

\begin{abstract}
Upwelling of nutrient rich waters into the sunlit surface layer of the ocean supports high primary productivity in Eastern Boundary Upwelling Systems (EBUS). However, subsurface waters not only contain macronutrients (N, P, Si) but also micronutrients, organic matter, and seed microbial communities that may modify the response to macronutrient inputs via upwelling. These additional factors are often neglected when investigating upwelling impacts on surface ocean productivity.

20 Here, we investigated how different components of upwelled water (macronutrients, organic nutrients, seed communities) drive the response of surface plankton communities to upwelling in the Peruvian coastal zone. Results from our short term (10 days) study show that the most influential drivers in upwelled deep water are 1) the ratio of inorganic nutrients $\left(\mathrm{NO}_{x}: \mathrm{PO}_{4}{ }^{3-}\right)$ and 2) the microbial community present that can seed heterogeneity in phytoplankton succession and modify stoichiometry of residual inorganic nutrients after phytoplankton blooms. Hence, this study suggests that phytoplankton succession after upwelling is modified by factors other than the physical supply of inorganic nutrients. This would likely affect trophic transfer and overall productivity in these highly fertile marine ecosystems.
\end{abstract}

\section{Introduction}

The Humboldt Current System (HCS) in the South Pacific Ocean is considered the most productive in terms of fish production and spans the coasts of northern Peru to Chile between 5 and $\sim 45^{\circ} S$ (Chavez and Messié, 2009). Alone the northern HCS off the Peruvian coast constitutes up to $20 \%$ of global industrial fish landings (Tarazona and Arntz, 2001) at a value of over $\$ 2 \mathrm{bn}$ USD to the Peruvian economy annually from exports in 2013 (Humala Tasso et al., 2015). This immense fish productivity is sustained by significant primary production, underpinned by wind driven upwelling along the continental shelf which occurs seasonally along the Chilean coast and almost permanently in the northern Humboldt Current off the Peruvian coast (Kämpf and Chapman, 2016). South easterly trade winds push surface waters offshore and westward towards the South Pacific subtropical gyre via Ekman transport. This movement induces upwelling of nutrient rich subsurface waters originating primarily in the poleward Peru-Chile Under Current (PCUC, Gutiérrez et al. (2016)) to the sunlit surface ocean, where primary producers assimilate the inorganic nutrients into organic matter.

However, the nutrient influx into the euphotic zone depends not only on the intensity of the wind-driven upwelling but also the characteristics of the source water present in the Ekman layer from which the upwelling occurs. For example, seasonal 
https://doi.org/10.5194/bg-2022-44

Preprint. Discussion started: 8 March 2022

(c) Author(s) 2022. CC BY 4.0 License.

fluctuations in the strength of northward flowing Sub-Antarctic Water (SAW), and southward flowing Equatorial Sub-Surface Water (ESSW) undercurrents can modify the source water oxygen and nutrient concentrations for coastal wind driven upwelling (Kämpf and Chapman, 2016). Changes in thermocline and nutricline depth due to interannual El Niño-Southern Oscillation (ENSO) phases has a similar impact on the upwelling source waters even if the upwelling depth does not change (Espinoza-Morriberón et al., 2017).

Another defining feature of HCS ecosystems is the extensive oxygen minimum zone (OMZ) in the eastern tropical south Pacific, extending up to $1000 \mathrm{~km}$ from the coast and over $600 \mathrm{~m}$ thick (Fuenzalida et al., 2009). These subsurface oxygen deficient waters are a result of a combination of three factors: oxygen-poor equatorial source water feeding the PCUC, slow ventilation, and high consumption of oxygen due to remineralisation of organic matter maintaining this oxygen deficiency

50 (Pennington et al., 2006). Low oxygen concentrations facilitate significant loss of fixed nitrogen via anaerobic microbial metabolism (annamox and denitrification, Lam et al. (2009)) and redox-dependent inputs of phosphate (P) and iron (Fe) from shelf sediments (Bruland et al., 2005). Thus, a biogeochemical imprint of nitrate (N) deficiency and an excess of P prevails in the inorganic nutrient stoichiometry of waters upwelled along the Peruvian shelf.

Cross-shelf shifts in the dominant primary producers have been linked to not only nutrient concentrations but also the relative proportion of N to P present (Franz et al., 2012; Meyer et al., 2017). Generally speaking, coastal phytoplankton communities on the Peruvian shelf in the northern HCS are dominated by diatoms or dinoflagellates, rapidly growing phytoplankton groups which capitalise on the abundance of inorganic nutrients in the freshly upwelled water along the shelf. Although N:P ratios are low in the upwelled water, the high concentrations mean that these groups have the luxury of assimilating nutrients in close to Redfield proportions which meets their physiological requirements for growth and nutrient acquisition (Arrigo, 2005). In

60 nutrient deplete water further offshore, smaller phytoplankton such as picocyanobacteria become more abundant (Franz et al., 2012).

Indeed, blooms of different phytoplankton populations can easily be induced experimentally by the addition of inorganic nutrients with a different N:P (Czerny et al., 2016; Hauss et al., 2012). However, addition of inorganic nutrients to a surface community neglects the dilution of the surface community when deep water with lower phytoplankton abundances is mixed upon upwelling. This would drive a phytoplankton-dominant response and modify trophic relationships between consumers and phytoplankton in a similar way to eutrophication studies (Taylor et al., 1995). Messie and Chavez (2015) suggest this dilution effect may underlie the Peruvian productivity paradox where highest upwelling is out of phase with the highest detected surface chlorophyll concentrations (Chavez and Messié, 2009). Furthermore, subsurface waters in the region have dissolved organic matter concentration and composition (Loginova et al., 2019), and trace metal concentrations that are different to those in surface waters and depends on the history of the water. For example, this can be influenced by the predominance of heterotrophic organisms in aphotic subsurface waters (e.g. Schmidt et al., 2016) and contact of sub- or anoxic water with sediment on the seafloor (Bruland et al., 2005). This may also modify the response of the surface plankton assemblage.

While surface phytoplankton blooms in upwelling regions are stimulated mostly by the nutrients brought to the surface, the

75 key phytoplankton group can be altered by organisms in the deep water also brought to the surface that can seed these blooms. Recently sunk algal cells or dormant life stages of diatoms or dinoflagellates (Smayda and Trainer, 2010) may be present or reintroduced via resuspension of cells in surface sediments (Ishikawa and Furuya, 2004) to aphotic subsurface waters where upwelling occurs from. Once exposed to light in the photic zone and combined with the nutrient rich upwelled water, these resting algal cells or spores can germinate thereby inoculating a fresh bloom (Carreto et al., 2016). Horizontal mixing of surface

80 waters following relaxation of vertical upwelling or along fronts can also introduce new phytoplankton populations that can propagate blooms spatially and lead to a succession in the dominant phytoplankton groups (Smayda and Trainer, 2010).

A mesocosm study investigating the impacts of upwelling and nutrient stoichiometry on the northern Humboldt Current System pelagic ecosystem was carried out during 2017 (Bach et al. 2020). This study primarily looked at the ecosystem level response of a natural surface plankton community in terms of biogeochemistry and ecology to addition of subsurface waters, but cannot disentangle which characteristic/s (inorganic nutrient concentrations and stoichiometry, dissolved organic nutrient and trace metal signature, subsurface plankton community) drives this response. Hence, we designed a complimentary experiment to investigate these three drivers on the lower food web response more in depth and in parallel to the mesocosm study. In particular we wanted to understand what impact does the subsurface-water chemistry (inorganic nutrients, organic nutrients) and biology 
https://doi.org/10.5194/bg-2022-44

Preprint. Discussion started: 8 March 2022

(c) Author(s) 2022. CC BY 4.0 License.

(seed populations) have on phytoplankton bloom biomass and phytoplankton community composition and succession and

\section{Materials and methods}

\subsection{Experimental setup and sampling procedures}

On $16^{\text {th }}$ March 2017, subsurface water from two stations (Station A: $12^{\circ} 02,840 \mathrm{~S} ; 077^{\circ} 17,064 \mathrm{~W}$; Station B: $12^{\circ} 02,249 \mathrm{~S}$; $77^{\circ} 40,123 \mathrm{~W}$ ) were collected using the research vessel B.I.C. Humboldt (Fig. 1). These stations are part of the Linea Callao

95 time series transect that is regularly sampled for inorganic nutrient concentrations and water column properties by Instituto del Mar del Peru (IMARPE). This data indicated that the offshore station (A) and more coastal station (B) usually have different nutrient profiles, in particular nitrate concentrations (see e.g. Graco et al., 2019).

Figure 1: Map of sampling locations off the Peruvian coast indicating collection sites and characteristics of water used in the incubations.

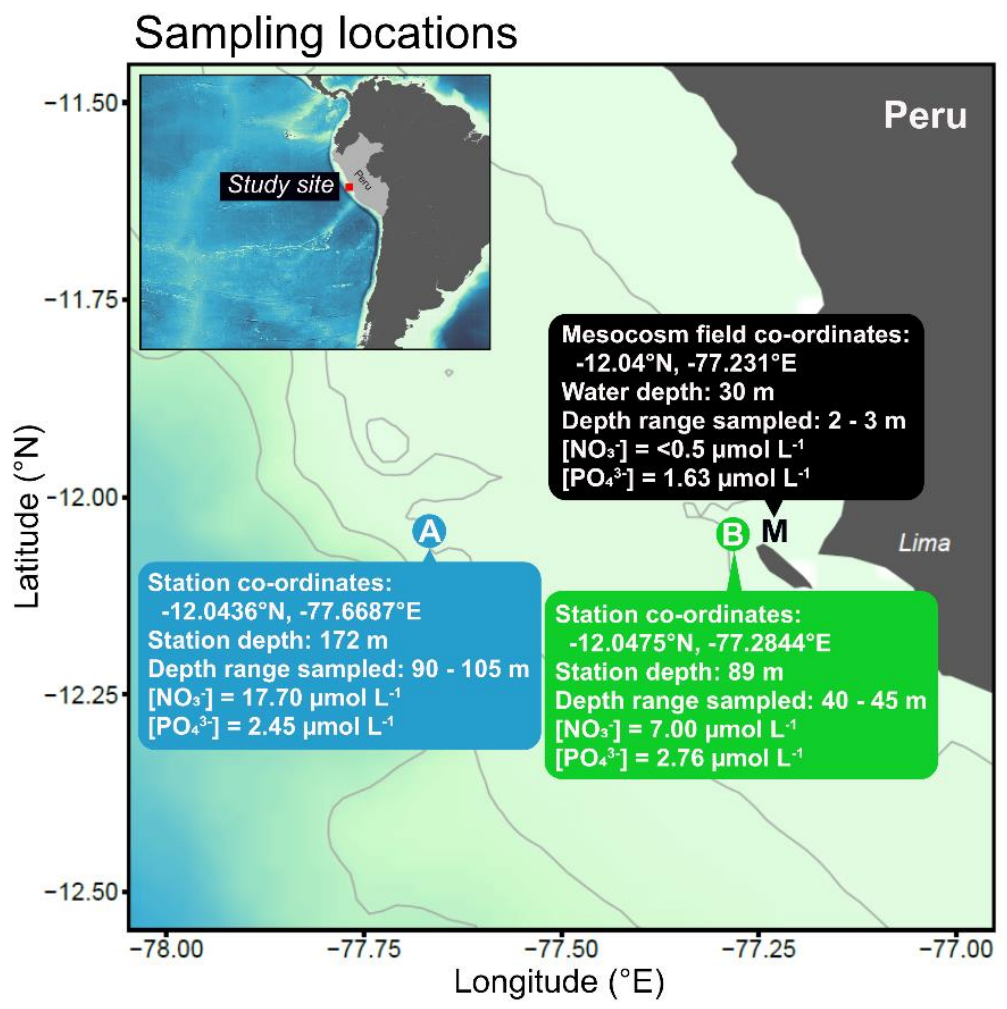

CTD profiles (CTD60M probe, Sea and Sun Technology) were performed at both stations along the entire water column $(<150$ $\mathrm{m}$ ) where oxygen $\left(\mathrm{O}_{2}\right)$ and hydrogen sulphide $\left(\mathrm{H}_{2} \mathrm{~S}\right)$ concentrations were used to indicate oxygenated and non-sulfidic waters

105 likely containing inorganic nitrogen. A total of $100 \mathrm{~L}$ of seawater by station was collected over a depth range of $15 \mathrm{~m}$ at each site (Fig. 1). Subsamples for precise measurement of nutrient concentrations were taken from each carboy, filtered $(0.45 \mu \mathrm{m}$ Sterivex) and stored cold until analysis on the same day on shore (see Sect. 2.2 for details on methods of nutrient analysis). Note, although this subsurface water was collected at modest depths, it is hereafter referred to as "deep water" to clearly 
https://doi.org/10.5194/bg-2022-44

Preprint. Discussion started: 8 March 2022

(c) Author(s) 2022. CC BY 4.0 License.

distinguish it from surface waters collected from the mesocosms. One day later (17 $7^{\text {th }}$ March 2017, Day 20 of mesocosm study), $40 \mathrm{~L}$ of nutrient depleted surface water was collected from the photic, oxic layer in five of the eight mesocosms (Station Mesocosm; M1-5, see Bach et al. (2020) for more details) using a manual vacuum pump system (pressure < 300 mbar) and was pooled in carboys. Precise sampling locations, depths and measured nutrients of collected water are summarised in Fig. 1.

The experiment was setup with three distinct treatments as detailed in Fig. 2 to distinguish the impact of inorganic nutrient ratio ("inorganic", nitrate:phosphate), organic nutrients and micronutrients such as trace metals ("organic"), and the seed microbial community ("biology") between the two different deep water sources (HN = high nitrate, LN = low nitrate). Two different nitrate $(\mathrm{N})$ concentrations were selected to distinguish the impact of nitrate concentration and N:P stoichiometry on the plankton response patterns. While no trace metal or dissolved organic nutrients measurement were made from this study to characterise the deep water sources, these were assumed to be different between Station A and B, just as the inorganic 120 nutrient concentrations were.

Figure 2: Experimental design including treatment information and defining characteristics. Three treatments were set-up using a mixture of inorganic nutrient addition to filtered surface water (inorganic nutrient), filtered and unfiltered deep water (organic and biology, respectively). Each of the six treatments had four replicates to compare the effect of these three treatments between different deep waters with different nutrient stoichiometry. These treatments were set-up for the two deep waters collected (LN $=$ low nitrate, and $\mathrm{HN}=$ high nitrate).

\begin{tabular}{|c|c|c|c|}
\hline & $\begin{array}{l}\text { Deepwater } \\
\text { nutrient status } \\
\text { and station }\end{array}$ & $\begin{array}{c}\text { Colour } \\
\text { code }\end{array}$ & Treatment characteristics \\
\hline \multirow{2}{*}{$\begin{array}{c}\text { INORGANIC } \\
50 \% \text { unfiltered surface water } \\
+ \\
50 \% \text { filtered surface water }\end{array}$} & $\underset{\text { Station A }}{\mathbf{H N}}$ & & \\
\hline & $\begin{array}{c}\mathbf{L N} \\
\text { Station B }\end{array}$ & & \\
\hline \multirow{2}{*}{$\begin{array}{c}\text { ORGANIC } \\
\text { 50\% unfiltered surface water } \\
+ \\
50 \% \text { filtered deep water }\end{array}$} & $\underset{\text { Station A }}{\mathbf{H N}}$ & & DOM / TM \\
\hline & $\begin{array}{c}\mathbf{L N} \\
\text { Station B }\end{array}$ & & $\mathrm{DOM} / \mathrm{TM}$ \\
\hline \multirow{2}{*}{$\begin{array}{c}\text { BIOLOGY } \\
50 \% \text { unfiltered surface water } \\
+ \\
50 \% \text { unfiltered deep water }\end{array}$} & $\underset{\text { Station A }}{\mathbf{H N}}$ & & DOM / TM \\
\hline & $\begin{array}{c}\mathbf{L N} \\
\text { Station B }\end{array}$ & & DOM / TM \\
\hline
\end{tabular}

Before the experiment, all water was prefiltered using $64 \mu \mathrm{m}$ gauze to remove large predators such as copepods and gelatinous organisms that are patchily distributed and could exert unequal grazing pressure in these low volume (15 L) incubations. Both the surface (mesocosm) and treatment water (deep water) were filtered stepwise over gauze down to $10 \mu \mathrm{m}$ mesh size, followed by sterile filtration using filter cartridges $(0.1 \mu \mathrm{m}$, Whatman Polycap TC 36).

After this filtration process, experimental treatments were set up in mixing ratios of 1:1 surface water:treatment water. For the "inorganic" nutrient treatment, $100 \mathrm{~L}$ of filtered mesocosm surface water $(0.1 \mu \mathrm{m})$ was mixed with $100 \mathrm{~L}$ of unfiltered $(64$ $\mu \mathrm{m})$ mesocosm surface water. The nitrate and phosphate concentrations in the inorganic treatment (no deep water) were set to the same level as in the organic and biology treatments (filtered/unfiltered, nutrient rich, deep water added) by adding stock 
https://doi.org/10.5194/bg-2022-44

Preprint. Discussion started: 8 March 2022

(c) Author(s) 2022. CC BY 4.0 License.

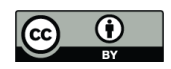

solutions of sodium nitrate $\left(\mathrm{NaNO}_{3}\right.$, EMPLURA®, Merck, Germany) and potassium dihydrogen phosphate $\left(\mathrm{KH}_{2} \mathrm{PO}_{4}\right.$, EMSURE® ISO for analysis, Merck, Germany) dissolved in MilliQ.

In the "organic" treatment, $100 \mathrm{~L}$ of filtered deep water from either Station A (high nitrate) or B (low nitrate) was mixed with $100 \mathrm{~L}$ of unfiltered surface mesocosm water. In the "biology" treatment, $100 \mathrm{~L}$ of unfiltered deep water from either Station A

or B was mixed with $100 \mathrm{~L}$ of unfiltered surface mesocosm water.

All six treatments were prepared in separate clean large plastic rainwater tanks ( $300 \mathrm{~L}$ volume) and carefully mixed before distributing among the four replicate flexible $15 \mathrm{~L}$ incubation containers per treatment and per deep water. Initial samples for inorganic nutrient analysis and determination of phytoplankton abundances by flow cytometry were collected in duplicate for each replicate when filled. Once all 24 containers were filled, they were randomly placed in incubator tubs covered with light

145 foil with 25\% transmittance (Blue Lagoon, LEE filters) under natural light and submerged in natural seawater using a flowthrough water system to maintain ambient temperature. A submersible logger (HOBO pendant Temperature/Light Data Logger, Onset Computer Corporation, MA, U.S.A) measured mean temperature of $23.1 \pm 3.5^{\circ} \mathrm{C}$ (s.d.) over the 10 day study period with the variability due to differences between day and night. The logger was shifted between incubators daily to measure conditions in all incubators. To calibrate the illuminance measured by the HOBO loggers to irradiance (PAR), we

150 attached the logger to a CTD with a Photosynthetically Active Radiation (PAR) sensor (CTD60M probe, Sea and Sun Technology) and submerged this in $\sim 1 \mathrm{~m}$ water depth between 11:50 and 17:00 on $14^{\text {th }}$ April. Using a calibration (Fig. S1), we estimated an average PAR of $250 \mu \mathrm{mol}$ quanta $\mathrm{m}^{-2} \mathrm{~s}^{-1}$ during daylight hours.

Subsampling for inorganic nutrient concentrations and phytoplankton abundances were carried out daily and for all other variables (Chlorophyll $a(\mathrm{Chl} a)$, enzyme rates, photophysiology and dissolved organic matter) approximately every $2^{\text {nd }}$ day from the incubation containers starting at 08:30 for 10 days between the $19^{\text {th }}$ and $28^{\text {th }}$ March 2017.

\subsection{Inorganic nutrient analyses}

One subsample per replicate for inorganic nutrient analyses were prefiltered $(0.45 \mu \mathrm{m}$, Sterivex, Merck) into acid cleaned tubes before analysis on a continuous flow analyser (QuAAttro Autoanalyser, SEAL Analytical) using an autosampler (XY2 autosampler, SEAL Analytical) and a fluorescence detector (FP-2020, JASCO). Nitrate $\left(\mathrm{NO}_{3}{ }^{-}\right)$and nitrite $\left(\mathrm{NO}_{2}{ }^{-}\right)$were 160 determined colorimetrically according to Morris and Riley (1963), while silicate $\left(\mathrm{Si}(\mathrm{OH})_{4}\right)$ and phosphate $\left(\mathrm{PO}_{4}{ }^{3-}\right)$ concentrations were determined colorimetrically according to Mullin and Riley (1955). Average limit of detections (LOD) were $0.123 \mu \mathrm{mol} \mathrm{L}^{-1}, 0.054 \mu \mathrm{mol} \mathrm{L}^{-1}, 0.033 \mu \mathrm{mol} \mathrm{L}^{-1}$ and $0.336 \mu \mathrm{mol} \mathrm{L}^{-1}$ for nitrate, nitrite, phosphate and silicate, respectively. Further details on measurements and their precision can be found in Bach et al. (2020).

\subsection{Chlorophyll a and phytoplankton community composition analyses}

165 A subsample from each replicate container were taken on Day 1, then every $2^{\text {nd }}$ day from Day 2 until Day 10 . Volumes of between $200-400 \mathrm{~mL}$ were filtered (pressure $<200 \mathrm{mbar}$ ) onto glass fibre filters $(\mathrm{GF} / \mathrm{F}, \varnothing 25 \mathrm{~mm}$, nominal pore size $0.7 \mu \mathrm{m}$, Whatman) with care taken to minimise exposure to light. Filters were stored at $-20^{\circ} \mathrm{C}$ until extraction and analysis. Chl $a$ was extracted from the filters in $90 \%$ acetone in plastic vials using glass beads and a cell mill to homogenise the cells from the filters. Concentrations were measured in the supernatant according to Welschmeyer et al. (1994) on a Turner 10-AU 170 fluorometer.

In addition, seawater samples for phytoplankton community analysis were collected in $2 \mathrm{~mL}$ cryovials and measured on the same day without fixation on an Accuri Flow cytometer. Individual particles were gated into groups based on size-fractions (picoeukaryotes, small microphytoplankton, larger microphytoplankton, nanophytoplankton), taxonomic groups (Synechoccocus, cryptophytes) and other forms (chains and group 'FL4') based on fluorescence signal and other properties 175 such as size and shape using forward/side scatter measurements. The "chain" group was distinguished by dividing the Chl $a$ red fluorescence amplitude by Chl $a$ red fluorescence height to class elongated cells, such as chain forming diatoms, by an elongated fluorescence signal. "FL4" were classed as very small particles that may be individual chloroplasts but could not be attributed to any likely phytoplankton group. An example cytogram to indicate the gating applied is provided in the Supplementary Material (Fig. S2). 
https://doi.org/10.5194/bg-2022-44

Preprint. Discussion started: 8 March 2022

(c) Author(s) 2022. CC BY 4.0 License.

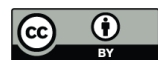

\subsection{Extracellular enzyme activity (leucine aminopeptidase)}

The leucine aminopeptidase (LAP) activity was determined using L-leucine 7-amido-4-methyl-coumarin (Leu-AMC; Sigma Aldrich) as a substrate (Stoecker and Gustafson, 2003). Leu-AMC was added to a final concentration of $500 \mu \mathrm{mol} \mathrm{L} \mathrm{L}^{-1}$, which was determined in separate kinetics tests to saturate the enzyme activity. The samples (200 $\mu$ l, except $400 \mu l$ on Day 1$)$ were incubated in the dark at in situ surface temperature for a minimum of four hours. The fluorescence was measured every 30-60 min with a Cary Eclipse (Agilent Technologies) spectrofluorometer using $380 \mathrm{~nm}$ excitation and $440 \mathrm{~nm}$ emission wavelengths. The results were compared with a standard curve determined using 7-amino-4-methyl-coumarin (AMC; Sigma Aldrich) dissolved in dimethyl sulfoxide (DMSO), and the LAP activity calculated by linear regression.

\subsection{Fast Repetition Rate Fluorometry (FRRF) and Chromophoric Dissolved Organic Matter (CDOM) analyses}

The samples for Fast Repetition Rate Fluorometry (FRRF) were collected alongside Chl $a$ and community structure in dark 190 plastic bottles $(125 \mathrm{~mL})$ in order to avoid cells damage during the sampling period $(<1 \mathrm{~h})$. To ensure dark adaptation of phytoplankton cells before analysis, samples were stored under darkness and at in situ room temperature for at least 30 min right after they had arrived in the facilities of the Instituto del Mar del Perú (IMARPE). Afterwards, 3 subsamples plus a blank of each treatment were analysed by means of a Fast Induction and Relaxation (FIRe) technique and system (for detailed information about FIRe see Gorbunov and Falkowski (2004)). The blanks were obtained gravitationally filtering water samples

195 through polycarbonate filters (PC, Ø $25 \mathrm{~mm}$, pore size $0.2 \mu \mathrm{m}, \mathrm{DHI})$ and subtracted from the corresponding sample signal. FIRe cuvettes were regularly cleaned (every $10-12$ samples) with $5 \% \mathrm{HCl}$ and gently rinsed with $\mathrm{MQ}$ water to avoid fouling. The maximum photochemical efficiency $\left(\mathrm{F}_{\mathrm{v}} / \mathrm{F}_{\mathrm{m}}\right)$ and the effective absorption cross-section of PSII $\left(\sigma_{\mathrm{PSII}}, \mathrm{A}^{2}\right.$. quanta $\left.{ }^{-1}\right)$ were estimated from FIRe profiles based on the biophysical model in Kolber et al. (1988).

Chromophoric Dissolved Organic Matter (CDOM) samples were measured as described in Catalá et al. (2018). Potential photobleaching during sampling and transportation was prevented using amber glass bottles $(75 \mathrm{~mL})$ for sample collection. A modular spectrophotometer (Ocean Optics) consisting of a USB2000+UV-VIS ES detector connected via optical fibres to a DH2000BAC light source and to a $100 \mathrm{~cm}, 250 \mu \mathrm{L}$ capillary (LPC100CM; World Precision Instruments; WPI) was used to measure CDOM absorption spectra from 200 to $900 \mathrm{~nm}$ at $1 \mathrm{~nm}$ intervals. Before analysis, the samples were gravitationally filtered through previously precombusted $\left(5 \mathrm{~h}\right.$ at $\left.450^{\circ} \mathrm{C}\right)$ glass fibre filters $(\mathrm{GF} / \mathrm{F}, \varnothing 25 \mathrm{~mm}$, nominal pore size $0.7 \mu \mathrm{m}$, Whatman) and then ran through the system at a constant rate of $1 \mathrm{~mL} \mathrm{~min}^{-1}$. Constant flow rate was achieved by means of a peristaltic pump (ISMATEC). MQ water blanks were analysed after every sample. Absorption coefficients $\left(\mathrm{m}^{-1}\right)$ at $254 \mathrm{~nm}$ $\left(a_{254}\right), 250 \mathrm{~nm}\left(a_{250}\right)$ and $365 \mathrm{~nm}\left(a_{365}\right)$ were calculated following Green and Blough (1994). $a_{254}$ has been used as DOC concentration proxy in the ocean (Catalá et al., 2018; Lønborg and Álvarez-Salgado, 2014), while the ratio of $a_{250}$ and $a_{365}$ $\left(\mathrm{E}_{2}: \mathrm{E}_{3}\right)$ is commonly used as an indicator of DOM molecular weight (MW, Helms et al. (2008)).

\section{$210 \quad 2.6$ Statistical analyses}

All statistical tests were carried out in the R environment (R Core Team, 2020). A non-parametric analysis of similarity test (ANOSIM) was carried out to determine if the difference in phytoplankton composition between the treatments (among group similarity) was smaller or larger than that between treatment replicates (within group similarity). Data were grouped by bloom status $($ pre-bloom $=$ Day $1-2$, bloom $=$ Day 3-4, post-bloom $=$ Day 8-10) to enable detection of treatment-related differences

215 in initial phytoplankton composition. A Bray-Curtis dissimilarity matrix was constructed and the stress was calculated and accepted if less than 0.2 , using the 'vegan' package in the R software (Oksanen et al., 2019). SIMPER (similarity percentages) were calculated post hoc on the Bray-Curtis distance matrix to distinguish influential groups behind the detected numerical dissimilarity.

We employed a linear mixed effects model using the 'nlme' package in the R software (Pinheiro et al., 2020) to test the impact of treatment. The linear model is robust against missing data points, meaning a consistent test could be employed across all dependent variables and heteroscedasticity (variability within replicates) could be taken into consideration as a result through a variable model variance structure in the linear mixed model. The initial model (fixed effects $=$ treatment $*$ deep water $*$ sampling day, random effects $=\sim 1$ | Incubation bottle) was simplified stepwise to retain only the terms that remained significant 
https://doi.org/10.5194/bg-2022-44

Preprint. Discussion started: 8 March 2022

(c) Author(s) 2022. CC BY 4.0 License.

(c) (i)

\section{0 effect.}

to the model result. Treatment, deep water and sampling day were all included as factors (non-continuous) as independent 225 variables against the continuous dependent variable. The model simplification was applied to the bloom period (Day 1-4, until peak Chl $a$ concentrations) and post-bloom period (Day 5-10) separately due to the non-monotonic response and distinct biological responses between the two periods. The contrast matrix used is reported in Table 1 and shows that the organic treatment was used as the control for the linear mixed model analysis. Model significance hence refers to the difference between organic vs. biology and organic vs. inorganic to distinguish the biological treatment effect and the organic/trace metal

Table 1. Contrast matrix used to compare treatment effects in the linear mixed model applied to the bloom and post-bloom periods.

\begin{tabular}{ccc} 
Treatment & Contrast 1 & Contrast 2 \\
\hline Biology (unfiltered deep water) & 1 & 0 \\
Organic (filtered deep water - control) & -1 & -1 \\
Inorganic (surface water) & 0 & 1 \\
\hline Sum of contrasts & 0 & 0 \\
\hline
\end{tabular}

235 The impact of random effects was tested for both incubator and bottle number with no significant impact of either on the model. Where the QQ plot indicated that extreme values skewed the model and to resolve heteroscedasticity, $\log$ (fixed effects) was employed and the linear model re-simplified as described above. These results are reported for example as $\log ($ Chlorophyll). Outliers in model fit were identified in initial model fit and excluded from the final model fit when the residuals were outside the $95 \%$ confidence interval (CI). Identified outliers were solely detected and excluded in nutrient drawdown ratios ( $\triangle \mathrm{DIN}: \Delta \mathrm{DIP}$ and $\triangle \mathrm{DIN}: \Delta \mathrm{DSi})$. Post hoc tests were carried out on the interaction term using False Discovery Rate ("fdr") with q $=0.05$ in the package 'emmeans' in R software (Lenth, 2020). In general, time was considered relevant for the emergence of treatment effects as the bloom developed but was not considered an experimental factor. Hence post hoc test output is reported primarily for nutrient treatment (high nitrate or low nitrate) and treatment factor (inorganic nutrients, biology or organic as the control).

245 A two-way ANOVA test was applied using a Box-Cox transformation to determine differences in the ratio of DIN drawdown $(\Delta \mathrm{DIN})$ to maximum $\mathrm{Chl} a$ accumulation $(\Delta \mathrm{Chl} a$ ) between treatments and deep water, as well as the interaction between treatment and deep water. $\Delta \mathrm{DIN}: \Delta \mathrm{Chl} a$ for each replicate was defined as the maximum drawdown in inorganic nitrogen in relation to maximum biomass build-up (Chl $a$ concentrations as a biomass proxy) and was calculated according to Eq. (1):

$\Delta$ DIN : $\Delta$ Chl $a=\frac{\text { DIN }_{\text {initial }}-\text { DIN }_{\text {min }}}{\text { Chla }_{\text {max }}-\text { Chla }_{\text {initial }}}$

250 Where $\mathrm{DIN}_{\text {initial }}$ and $\mathrm{DIN}_{\min }$ are the initial and minimum concentrations of dissolved inorganic nitrogen, and Chla $\mathrm{amax}_{\max }$ Chla $a_{\text {initial }}$ are the maximum and initial Chl $a$ concentrations, respectively, with units of $\mu$ mol: $\mu \mathrm{g}$. Assumptions of the model fit after data transformation were tested using Levene's test (heteroscedasticity) and Shapiro-Wilks test (normality of residuals) and indicated both assumptions were satisfied.

\section{Results}

\section{3.1 Initial conditions (Day 1)}

Initial nutrient concentrations were similar for the three sub-treatments for each deep water (Fig. 3) with $7.72 \pm 0.46 \mu \mathrm{mol} \mathrm{L}$ ${ }^{1}$ and $2.56 \pm 0.54 \mu \mathrm{mol} \mathrm{L}^{-1} \mathrm{NO}_{3}{ }^{-}$for high nitrate and low nitrate (mean \pm s.d., $\mathrm{n}=12$ ), respectively. An overview of all starting 
https://doi.org/10.5194/bg-2022-44

Preprint. Discussion started: 8 March 2022

(c) Author(s) 2022. CC BY 4.0 License.

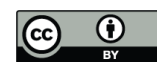

variables for the two deep water treatments is provided in Table S1 (Supplementary Material). A proxy for total DOC concentrations from CDOM measurements $\left(\mathrm{a}_{254}\right)$ had the highest initial values in the inorganic nutrient treatments and lowest concentrations in low nitrate treatments (both organic and biology). This was likely due to different concentrations in the deep water source that were lower than the mesocosm concentrations and hence diluted the DOC initially present in the treatments. No clear initial treatment differences were observed in the proxy of DOM molecular weight $\left(\mathrm{E}_{2}: \mathrm{E}_{3}\right.$, Fig. 4). LAP activity was slightly higher in the surface water (inorganic) treatments than in the organic or biology treatments, possibly a residual signal due to inorganic nitrogen depletion in the surface mesocosm water that was not diluted by the deep water nutrients added (Fig.

\section{$2653 \mathrm{~F})$}

Initial phytoplankton community composition based on relative contribution of each group to Chl $a$ fluorescence in flow cytometric analyses did indicate variability between replicates within a treatment but indicated no significant difference between either deep water nutrient status (high nitrate, low nitrate; $R$ statistic $=0.0313, p=0.131)$ or the treatment $(\mathrm{R}$ statistic $=0.0212, p=0.276)$. Maximum photochemical efficiency $\left(\mathrm{F}_{\mathrm{v}} / \mathrm{F}_{\mathrm{m}}\right)$ also presented small differences at the beginning of the

270 experiment $(0.49 \pm 0.01$, mean \pm s.d., $\mathrm{n}=24$, Fig. 4), that alongside with the no differences observed in Chl $a$ and community structure, suggest that phytoplankton initial conditions were similar in all treatments.

\subsection{Bloom phase (Day 2 - Day 5)}

Inorganic nutrients were rapidly consumed with exhaustion of inorganic nitrogen within 3-4 days (Fig. 3B). Silicate drawdown was the most marked in the "biology" treatment for high nitrate between Day 3 and 5. Peak Chl $a$ concentrations of up to 12

$275 \mu \mathrm{g} \mathrm{L}-1$ and $\sim 6 \mu \mathrm{g} \mathrm{L}^{-1}$ for high nitrate and low nitrate, respectively, were observed on Day 4 with significant treatment differences detected due to trace metals/organic deep water chemistry and the inorganic nutrient addition (Post hoc pairwise test, organic and inorganic nutrient treatments respectively, Tables S2a,b). The $\mathrm{F}_{\mathrm{v}} / \mathrm{F}_{\mathrm{m}}$ resembled $\mathrm{Chl} a$ concentration during the bloom phase with higher values in high nitrate than in low nitrate treatments. Nevertheless, while Chl $a$ peak and break down occurred at same time in both deep water treatments, $F_{v} / F_{m}$ peaked on Day 2 in low nitrate treatments and between Days 2 and 4 in high

280 nitrate treatments. Minimum $F_{v} / F_{m}$ after bloom peak were also reached at different times, on Day 6 and between Days 7 and 10 in low nitrate and high nitrate treatments, respectively.

Non-Redfield nutrient utilisation was observed after nutrient depletion on Day 4. Over 50\% more DIN compared to DIP was consumed in low nitrate than in high nitrate deep water treatments $(\Delta \mathrm{DIN}: \Delta \mathrm{DIP}$ on Day 10: low nitrate $=9.82 \pm 1.68$, high nitrate $=6.25 \pm 1.85$, mean \pm s.d., $\mathrm{n}=6$, Fig. $3 \mathrm{E}$, ). The ratio of DIN drawdown to maximum Chl $a$ accumulation was also 285 highest in the low nitrate deep water treatments where initial $\mathrm{N}$ was lowest $\left(\mathrm{F}_{(1,18)}=4.65, \mathrm{p}=0.045\right.$, Fig. $\left.4 \mathrm{~A}\right)$. The main effect of treatment and the interaction between treatment and deep water factors were not statistically significant $\left(\mathrm{F}_{(2,18)}=1.88, \mathrm{p}=\right.$ 0.181 ; and $\mathrm{F}_{(2,18)}=2.24, \mathrm{p}=0.135$, respectively). This difference in mean DIN drawdown to maximum Chl $a$ accumulation was up to 2.5 times higher in the high nitrate biology treatment compared to the low nitrate organic, thus indicating higher recycling of $\mathrm{N}$ or highest $\mathrm{N}$ utilisation efficiency under low nitrate. LAP activity during the bloom was similar to initial rates

$290\left(1.0-2.0 \mu \mathrm{mol} A M C \mathrm{~L}^{-1} \mathrm{~h}^{-1}\right)$ and where differences in activity between treatments were detected, were higher in the high nitrate treatments. The initial DIN concentrations were around 3 times higher in the high nitrate compared to the low nitrate treatments (Table S1).

Average phytoplankton cell size, indicated by mean forward scatter (FSC-A) from flow cytometric analyses, increased to reach a maximum on Day 5 coinciding with inorganic nitrogen depletion (Fig. 4C). The smallest and largest mean cell sizes were 295 observed in the low nitrate and high nitrate biology treatments, respectively. Divergence in average size between treatments occurred during the post-bloom period (after Day 6). 
https://doi.org/10.5194/bg-2022-44

Preprint. Discussion started: 8 March 2022

(c) Author(s) 2022. CC BY 4.0 License.

Figure 3: Measured A) Chlorophyll $a$ concentrations, B) nitrate + nitrite concentrations, C) phosphate concentrations, D) silicate drawdown, (E) calculated nutrient drawdown stoichiometry (nitrate+nitrite consumed vs. phosphate consumed), and (F) measured leucine aminopeptidase (LAP) activity over the 10 day study period. Dots indicate mean across four treatment replicates and the error bars indicate the corresponding calculated $95 \%$ confidence interval for each sampling day. The dashed line in (E) indicates the Redfield ratio of 16:1.
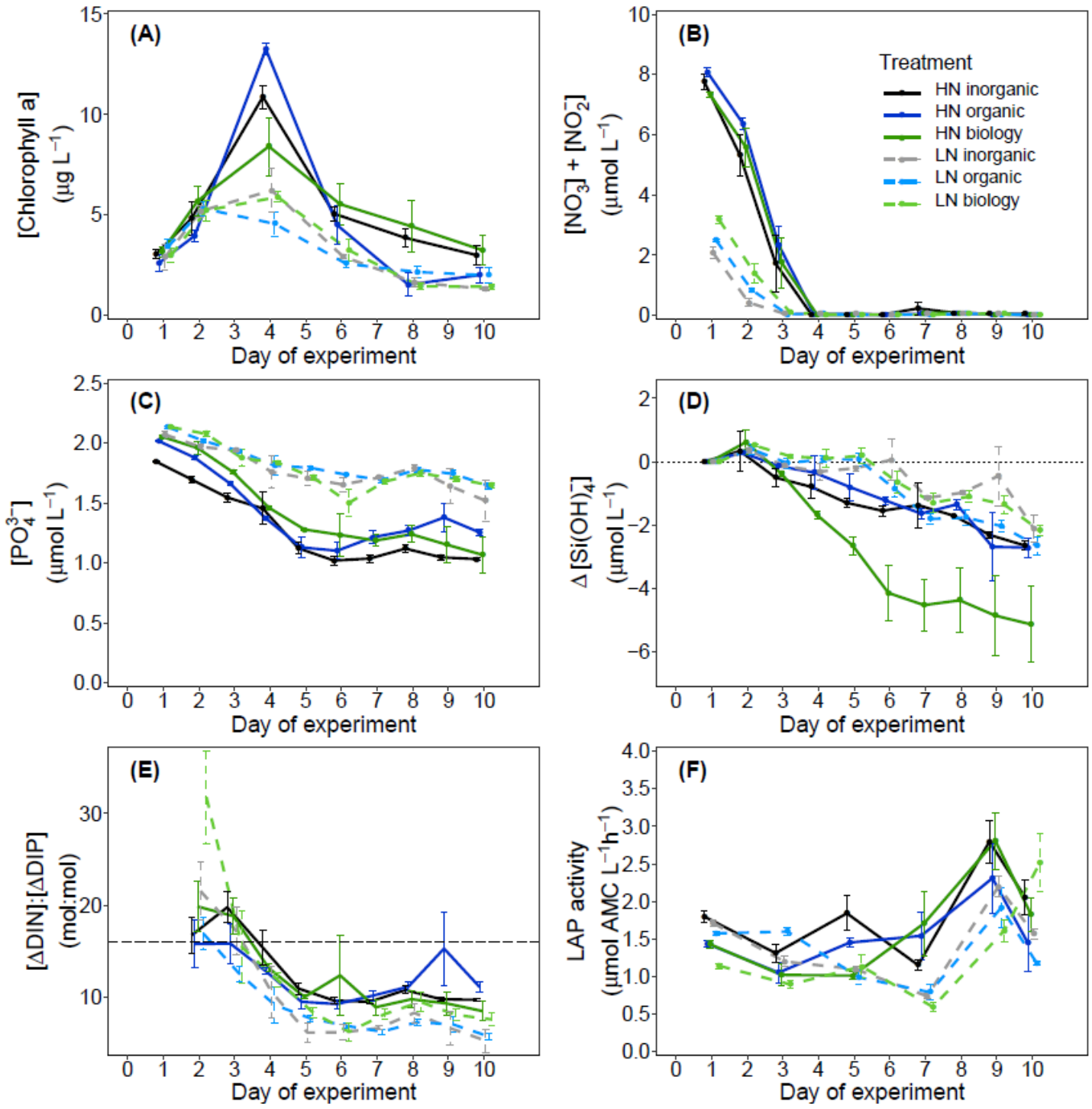
https://doi.org/10.5194/bg-2022-44

Preprint. Discussion started: 8 March 2022

(c) Author(s) 2022. CC BY 4.0 License.

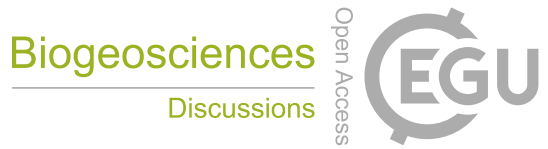

(c) (i)

Figure 4: A) Ratio of inorganic nitrate uptake to maximum accumulated Chl $a$ concentrations, B) mean relative drawdown in nitrate to phosphate during the post-bloom period (Days 6-10), C) mean forward scatter (FSC-A) from flow cytometric analyses as a proxy

315 of relative phytoplankton cell size during the study period, D) maximum photochemical efficiency $\left.\left(\mathbf{F}_{\mathrm{v}} / \mathbf{F}_{\mathrm{m}}\right), \mathbf{E}\right)$ absorption coefficient at $254 \mathrm{~nm}\left(a_{254}\right)$ used as a proxy for DOC concentration, and F) the ratio of the absorption coefficients at $250 \mathrm{~nm}$ and $365 \mathrm{~nm}\left(\mathrm{E}_{2}: \mathrm{E}_{3}\right)$ as an indicator of DOM molecular weight. Individual symbols in A) and B) indicate replicate incubations.

https://doi.org/10.5194/bg-2022-44

Preprint. Discussion started: 8 March 2022

(c) Author(s) 2022. CC BY 4.0 License.

\section{Post-bloom phase (Day 6 - Day 10)}

320 Chl $a$ concentrations on Day 10 decreased to similar concentrations as the initial measurements on Day 1 indicating decline in phytoplankton biomass (Fig. 3A). In the high nitrate biology treatment, there were marked differences in silicate uptake between the replicates. The highest $\mathrm{Si}(\mathrm{OH})_{4}$ and phosphate drawdown, and consequently $\mathrm{Chl} a$ concentrations and nanophytoplankton abundances was observed in one replicate. This indicated higher sustained phytoplankton growth, in particular in silicate-containing species, during the post-bloom phase.

325 In some treatments, phosphate concentrations slightly increased between Day 6 and Day 8, although there was no measurable change in nitrate concentrations. The subsequent consumption of this again from Day 8 to Day 10 coincided with upregulation of LAP (Fig. 3F), in particular on Day 9. Synechoccocus abundances increased in both biology treatments during the postbloom period (Fig. 5A-C) with an earlier increase in low nitrate treatment where initial nitrate concentrations were lower and presumably the phytoplankton reached nitrate-limited growth earlier. Initial abundances were similar between all six treatments $\left(10861 \pm 932\right.$ cells $\mathrm{mL}^{-1}$, mean \pm s.d., $\mathrm{n}=24$, Fig. 5), with treatment differences emerging after around Day 3.

Figure 5: Abundances of two key phytoplankton groups identified in flow cytometric analyses, Synechococcus (A-C) and nanoplankton (D-F), measured daily over the 10-day long study period. A divergent response was observed between biology treatment replicates in both groups during the nutrient-depleted post-bloom period after Day 4.
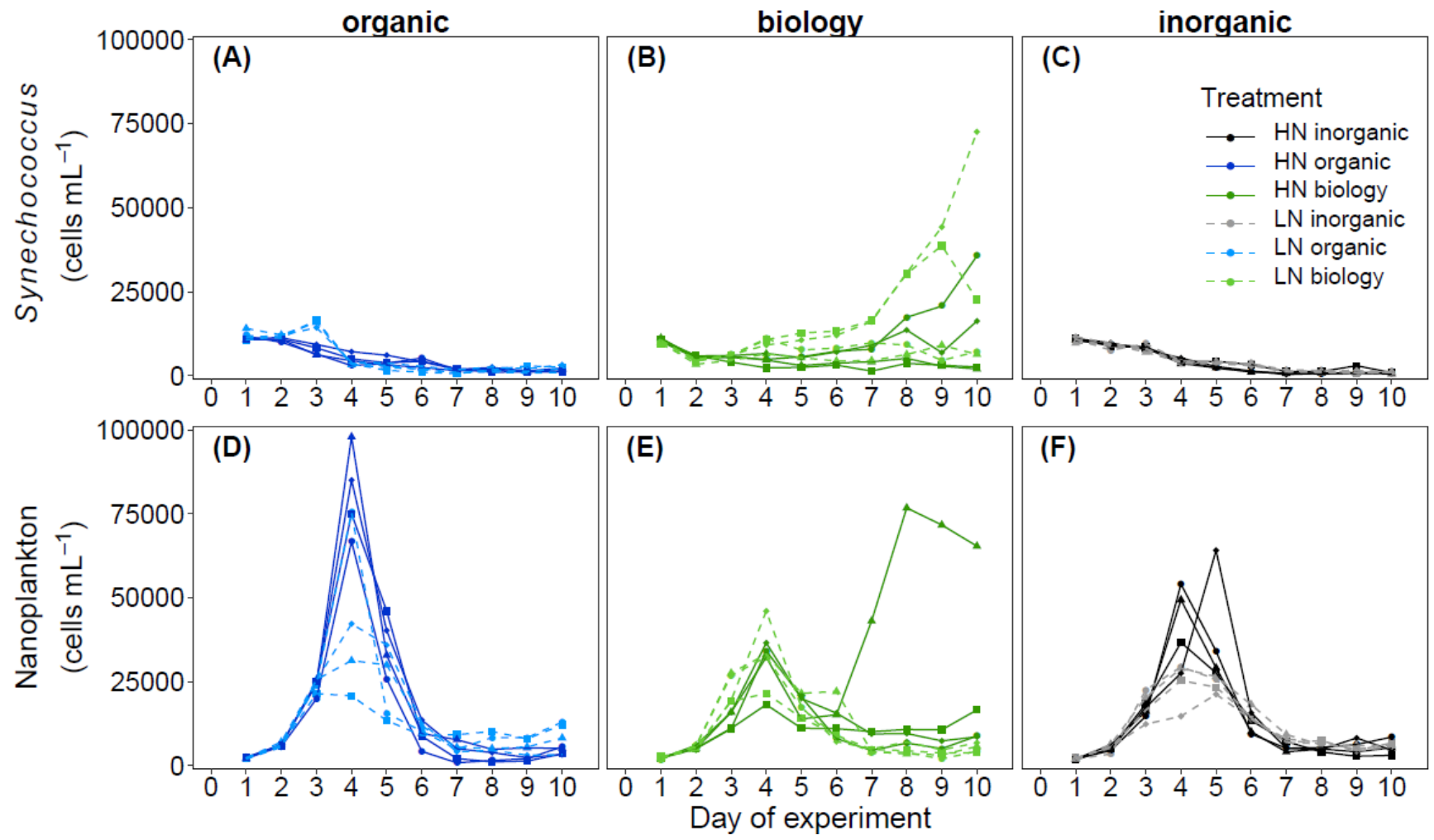
https://doi.org/10.5194/bg-2022-44

Preprint. Discussion started: 8 March 2022

(c) Author(s) 2022. CC BY 4.0 License.

Chl $a$ concentrations were significantly affected by treatment and nutrient status in the biology and inorganic nutrient treatments on Day 8 and Day 10 (Post hoc Tukey Pairwise comparison, Biology: $p_{\text {adj }}=0.0012$, $p_{\text {adj }}=0.0129$; Inorganic nutrients: $\mathrm{p}_{\mathrm{adj}}=0.051, \mathrm{p}_{\mathrm{adj}}=0.0087$, for Day 8 and Day 10, respectively. See also Table S2b in Supplementary Material). Community composition was also influenced by treatment and deep water nutrient status post-bloom (Table 2). Phytoplankton community composition was significantly affected by treatment during the post-bloom period, although the effect was weak $(\mathrm{R}=0.07601, \mathrm{p}=0.005)$ with an overall dissimilarity between treatments of $35-37 \%$ (Table 2 ).

Table 2: Results of one-way ANOSIM analyses and Post hoc SIMPER analyses reporting only significant differences in measured cell abundances, where detected, and the groups with the highest and significant contribution to these treatment differences.

\begin{tabular}{|c|c|c|c|c|c|c|c|}
\hline & Factor & $\underset{\text { statistic }}{\mathbf{R}}$ & $\begin{array}{c}\mathbf{p} \\
\text { value }\end{array}$ & Comparison & $\begin{array}{c}\text { Overall } \\
\text { dissimilarity } \\
\text { between } \\
\text { treatments }\end{array}$ & Key group & Contribution \\
\hline \multirow{6}{*}{$\sum_{\substack{0 \\
0}}^{1}$} & \multirow{6}{*}{$\begin{array}{l}\text { Treatment } \\
\text { (inorganic, } \\
\text { organic, } \\
\text { biology) }\end{array}$} & \multirow{6}{*}{0.2214} & \multirow{6}{*}{0.001} & $\begin{array}{l}\text { Biology vs. } \\
\text { Inorganic }\end{array}$ & $16.70 \%$ & Chains & $\begin{array}{l}3.37 \% \\
350\end{array}$ \\
\hline & & & & \multirow{3}{*}{$\begin{array}{l}\text { Biology vs. } \\
\text { Organic }\end{array}$} & \multirow{3}{*}{$19.02 \%$} & Nanophytoplankton & $7.57 \%$ \\
\hline & & & & & & Chains & $3.37 \%$ \\
\hline & & & & & & Picoeukaryotes & $1.75 \%$ \\
\hline & & & & \multirow{2}{*}{$\begin{array}{l}\text { Inorganic vs. } \\
\text { Organic }\end{array}$} & \multirow[t]{2}{*}{$16.05 \%$} & $\begin{array}{c}\text { Large } \\
\text { microphytoplankton }\end{array}$ & $3.61 \%$ \\
\hline & & & & & & Synechococcus & $0.46 \%$ \\
\hline \multirow{8}{*}{$\begin{array}{l}\sum \\
0 \\
0 \\
0 \\
0 \\
0 \\
0 \\
0 \\
0\end{array}$} & \multirow{2}{*}{$\begin{array}{l}\text { Deepwater } \\
\text { N:P }\end{array}$} & \multirow{2}{*}{0.04404} & \multirow{2}{*}{0.037} & \multirow{2}{*}{$\begin{array}{l}\text { High nitrate } \\
\text { vs. low nitrate }\end{array}$} & \multirow{2}{*}{$36.29 \%$} & Nanophytoplankton & $10.03 \%$ \\
\hline & & & & & & Synechococcus & $0.06 \%$ \\
\hline & \multirow{6}{*}{$\begin{array}{l}\text { Treatment } \\
\text { (inorganic, } \\
\text { organic, } \\
\text { biology) }\end{array}$} & \multirow{6}{*}{0.07601} & \multirow{6}{*}{0.005} & \multirow{2}{*}{$\begin{array}{l}\text { Biology vs. } \\
\text { Inorganic }\end{array}$} & \multirow[t]{2}{*}{$36.92 \%$} & $\begin{array}{c}\text { Small } \\
\text { microphytoplankton }\end{array}$ & $11.12 \%$ \\
\hline & & & & & & Synechococcus & $0.99 \%$ \\
\hline & & & & \multirow{3}{*}{$\begin{array}{l}\text { Biology vs. } \\
\text { Organic }\end{array}$} & \multirow{3}{*}{$37.17 \%$} & Picoeukaryotes & $4.28 \%$ \\
\hline & & & & & & Chains & $3.93 \% 355$ \\
\hline & & & & & & Synechococcus & $0.94 \%$ \\
\hline & & & & $\begin{array}{l}\text { Inorganic vs. } \\
\text { Organic }\end{array}$ & $35.28 \%$ & FL4A & $0.17 \%$ \\
\hline
\end{tabular}

\section{Discussion}

\subsection{Peak bloom biomass was affected by seed population in upwelled deep water}

360 As expected, nutrient addition from the deep water stimulated surface phytoplankton biomass production and increased average phytoplankton community cell size. This fits well with the general understanding of phytoplankton blooms in upwelling regions where larger phytoplankton, often diatoms, dominate bloom biomass as sporadic wind driven upwelling events bring nutrient rich subsurface water to the photic layer (Sydeman et al., 2014). In this study, higher initial nitrate concentrations generally lead to higher peak phytoplankton biomass and higher photosynthetic energy conversion efficiency $\left(\mathrm{F}_{\mathrm{v}} / \mathrm{F}_{\mathrm{m}}\right)$, as 
https://doi.org/10.5194/bg-2022-44

Preprint. Discussion started: 8 March 2022

(c) Author(s) 2022. CC BY 4.0 License.

expected (Falkowski et al., 2017). Hence, we consider the availability of inorganic nitrogen to be a primary factor controlling organic matter production in this truncated food web $(<64 \mu \mathrm{m})$.

However, while nitrate concentrations were the same between high nitrate treatments, bloom development was not. There were noticeable differences in peak bloom Chl $a$ concentrations between the high nitrate treatments (organic, inorganic and biology) of up to $6 \mu \mathrm{g} \mathrm{L}^{-1} \mathrm{Chl} a$. In particular, the unfiltered deep water treatment (high nitrate biology), testing the impact of the seed microbial community, had lowest peak $\mathrm{Chl} a$ concentrations. Sharper bloom biomass development in the filtered high nitrate organic and high nitrate inorganic treatments a primarily bottom-up driven food web response to nutrient addition, rather than any impact of grazing. Bloom development in high nitrate biology was more muted as nutrient competition within the plankton community (e.g. heterotrophic bacteria) was higher, either due to the lack of dilution compared to the filtered organic/inorganic nutrient treatments or via introduction of microzooplankton grazers $(<64 \mu \mathrm{m})$ in the addition of unfiltered deep water. Hence,

375 higher retention of $\mathrm{Chl} a$ post-bloom in this treatment, suggests potentially longer sustained periods of productive biomass when deep water plankton are added concurrently with upwelled nutrients.

Among the four replicate "biology" incubations with the same measured initial nutrient concentrations and proportions of surface and deep water and incubation light and temperature, there were also marked differences in maximum Chl $a$ concentrations that could not be explained by the amount of added nitrate. Divergence in Chl $a$ biomass within a given treatment (i.e. with the same initial nitrate concentrations) occurred after nitrate concentrations were below detection around Day 4. This indicates that flexible nitrogen assimilation strategies were employed by the same starting community to produce active primary producing biomass: nitrate was either internally stored in phytoplankton cells (Bode et al., 1997) and could not be detected in filtered nutrient analyses or alternative nitrogen sources were utilised e.g. dissolved organic nitrogen or rapid ammonia assimilation thereby supporting higher Chl $a$ biomass. Yet more importantly, these strategies must have been employed to a different degree of success. This variable response to nutrient additions contributes another layer of complexity when projecting primary producer responses to upwelling in the Peruvian Humboldt Current System. The variability between both the filtered and unfiltered deep water treatment, in addition to the variability between replicates in the unfiltered deep water treatment, suggest that the microbes present in subsurface waters are key drivers in the observed biomass response to upwelled waters in the euphotic zone.

390 Despite high variability in the biomass response - both between and within treatments - the consumption of excess phosphate (i.e. degree of non-Redfield nutrient uptake) was more dependent on the initial nitrate concentrations rather than the deep water biology. Our results also indicate that up to over 50\% more phosphate was consumed per mol of DIN in the low nitrate treatment with higher initial excess phosphate, than with high nitrate. Biological dinitrogen fixation was likely a minor source of new nitrogen compared to nitrate inputs during this time, as was found in the parallel mesocosm study (Kittu et al., n.d.).

395 We also have no evidence from enzyme rates measured, that there was any stimulation of microbial nutrient regeneration to satisfy $\mathrm{N}$ demand, despite $\mathrm{N}$-depletion. We had anticipated an upregulation in leucine aminopeptidase (LAP) activity, a protein-hydrolysing enzyme, where inorganic nitrate concentrations were lowest and hence most limiting in the low nitrate treatments. Instead, LAP activity was highest during the post-bloom period and in the high nitrate treatment where there was more semi-labile organic matter present, as indicated by higher signatures in $\mathrm{a}_{254}$ (a proxy of DOM) and $\mathrm{E}_{2}: \mathrm{E}_{3}$ (a proxy of more 400 labile high molecular weight compounds) (Benner and Amon, 2015). The LAP activity was one to two orders of magnitude higher than most literature values. For example, in a study from the same region but further from shore, the LAP activity was 20-65 nmol AMC L $\mathrm{L}^{-1} \mathrm{~h}^{-1}$ in natural communities (Maßmig et al., 2020). The high LAP activity and close relationship with fresh, labile organic matter production suggests that LAP was produced to support bacterial production above the oxycline (Loginova et al., 2019), rather than compensating for higher N-limitation in the low nitrate treatment.

\section{4.2 Seeding of deep water populations is a key driver for plankton succession and biogeochemistry in surface blooms}

We expected to have similar initial plankton assemblage composition in the organic and inorganic nutrient treatments as all plankton present originate from the surface mesocosm water. Differences in initial composition would be expected in the biology treatments due to addition of deep water communities from two different locations and depths but these were not significant in this study and no clear difference in initial abundances between treatments was detected in phytoplankton

410 according to flow cytometry data. Phytoplankton assemblage composition across all treatments converged during the bloom as rapid growing groups, probably diatoms based on flow cytometric size class and observed silicate consumption, dominated 
https://doi.org/10.5194/bg-2022-44

Preprint. Discussion started: 8 March 2022

(c) Author(s) 2022. CC BY 4.0 License.

overall biomass. Inherent variability in plankton community dynamics between treatments and among replicates, was revealed in nanoplankton and in Synechococcus, when resource availability (here, nitrate) limited net growth after Day 4. Post-bloom community composition on Day 10 was affected by deep water treatment although treatment differences were small. This 415 variability may have originated in the initially enclosed populations, even though we designed the study to minimise heterogeneity by pooling all treatments and continuously mixing the pooled treatments while randomly filling the replicate bottles. Hence, not only the absolute biomass concentrations as previously discussed, but also phytoplankton community composition post-bloom was determined by the seed microbial populations initially present.

We propose that different mechanisms drove the divergent response of phytoplankton community composition between treatments and between replicates, in particular for two key groups: Synechococcus, and nanoplankton/chain-forming species that were likely diatoms based on dissolved silicic acid consumption. Diatoms were likely beneficiaries of nutrient addition as they are considered "transcriptionally proactive" (Lampe et al., 2018). This means they can respond quickly and take advantage of nitrogen resources when sporadically available, for example during upwelling (Fawcett and Ward, 2011; Stolte and Riegman, 1995) or after nutrient inputs into nutrient poor surface waters in oligotrophic gyres (Lampe et al., 2019). Rapid nutrient uptake and growth by diatoms lead to their ecosystem dominance in nutrient-initiated phytoplankton blooms such as those in coastal upwelling systems (Lassiter et al., 2006). Silicate consumption post-bloom and more nanoplankton species in unfiltered treatments suggest resting spores or down welled chain-forming silicifying phytoplankton were indeed present in the subsurface waters, thriving when irradiance levels increased upon incubation. Moreover, distinct responses of the diatom community between the two deep water sources in the unfiltered "biology" treatments is further evidence that the seed population in upwelled waters modulates surface bloom dynamics of diatom populations in the Humboldt Upwelling System.

Initial cell abundances were similar in all treatments, and ANOSIM analyses did not detect any significant differences in community composition, thus the majority of the starting community stemmed from the mesocosm surface water, rather than the manipulated deep water. Lack of net Synechococcus growth in the organic treatments but growth in the unfiltered biology treatments with the same seawater chemistry (i.e. inorganic and organic nutrients and trace metals) points towards a mutually

435 beneficial relationship, either metabolic or ecological, between Synechococcus and an unidentified member of the unfiltered deep water plankton community $(<64 \mu \mathrm{m})$. For example, a change in dominant predators upon addition of deep water may have relieved grazing pressure on these picocyanobacteria. Alternatively, a metabolic response could be due to underlying induced changes in gene expression (Robidart et al., 2019) or a dependency (syntrophy) with a deep water microbe/organism may have evolved, selectively supporting the cooccurrence of Synechococcus and other microbes through complementary 440 metabolic function (Morris et al., 2012). There is also evidence that viral presence and lysis of heterotrophic bacteria may also enhance Synechococcus growth (Weinbauer et al., 2011). Slow growing picocyanobacteria lend themselves more to stable mutualistic relationships than faster growing diatoms that quickly consume resources and generally follow a 'boom or bust'like biomass trajectory. Hence, the different physiological response times - rapid in diatoms and comparatively slower in picocyanobacteria - appears to underlie the variability in biomass observed in this incubation experiment. The bloom 445 community contained higher diatom abundances, driven by initial but immeasurable differences in seed community enclosed, and the sustained differences emerging post-bloom in Synechococcus. The slower but more consistent growth of Synechococcus may indicate why these picocyanobacteria are often observed post-bloom and in more oligotrophic waters further offshore (Franz et al., 2012), even though the origins of their biomass can be apparently influenced by upwelling of nutrient rich water and the microbial communities contained within close to the coast.

450 The lack of consistent response in multiple variables (Chl $a$, silicate concentrations, phytoplankton abundances) across all "biology" treatment replicates further shows how heterogeneity in subsurface water seed communities can shape the resulting plankton bloom development, biomass accumulation and nutrient concentrations in surface waters. In addition to initial nitrate concentrations, the seed microbial population variability impacted final nutrient stoichiometries and in particular silicate:nitrate utilisation. Over $2.4 \mu \mathrm{mol} \mathrm{L}{ }^{-1}$ more silicate was consumed after nitrate was exhausted and higher post-bloom Chl $a$ concentrations were sustained in this treatment.

\subsection{Consequences for phytoplankton succession and productivity after upwelling events}

Natural variability in composition or fitness in initial plankton assemblages can bring about significant variability in measured response variables that can be larger than those driven by the treatment itself (Krishna and Schartau (2017)). Yet it is surprising 
https://doi.org/10.5194/bg-2022-44

Preprint. Discussion started: 8 March 2022

(c) Author(s) 2022. CC BY 4.0 License.

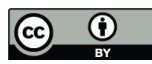

for such a strong driver of phytoplankton succession, like nitrate concentrations, that the deep water biology had such a measurable influence. A similar study in the southern (Chilean) Humboldt Current System investigated the impact of N:P ratios on different surface communities and came to the same conclusion: initial community composition was more important than inorganic N:P ratio for food web functioning and biogeochemistry (Spilling et al., 2019). Stable and consistent relationships between nutrient availability, consumption and the produced biomass are clearly not a feature of this dynamic ecosystem. The vital role of the seed population in modifying the bloom following upwelling events may even be a general characteristic of plankton communities in the Humboldt Current System, and other upwelling ecosystems.

Hence, nutrient upwelling promotes bloom development and phytoplankton growth while the upwelled community modulates these blooms in composition. This makes prediction of coastal phytoplankton productivity a particular challenge as the entrainment of subsurface populations depends on depth and rates of water mass transport and modulation of source water in either depth or location will likely reflect in altered ecology of bloom populations in coastal waters, and potential biogeochemical changes in nutrient cycling. This would be in addition to the variability in nutrient content of upwelled water sources via ENSO (Espinoza-Morriberón et al., 2017) and variability in the mixed layer depth (Rigby et al., 2020). It is even possible that this uncertainty would be amplified if this response occurred in a more complete food web with larger predators. Smaller organisms e.g. Synechococcus, that are less important for determining high biomass during the blooms, did not have clear impact on nutrient stoichiometry within the study time period despite clearly profiting from the addition of a deep water microbial community. Indeed, vertical mixing through Ekman pumping away from the coast may even provide sporadic stimulation of surface Synechococcus populations as water masses are advected offshore into the South Pacific subtropical gyre. In the ocean, physiological and ecological drivers (e.g. growth rates, transcriptional response times, mutualisms, symbioses, Sect. 4.2) would act in addition to other physical factors that regulate plankton biomass accumulation and succession in the surface waters following upwelling (e.g. seed community abundance present in subsurface waters (Seegers et al. 2015) that could not be included in this experimental set-up, such as dilution and mixing of water masses via regular tidal transport of water masses onshore (Stauffer et al., 2020).

\section{Conclusions}

Overall, productivity, i.e. organic matter production in this 10-day long incubation study, was highest in treatments with the highest added nitrate concentrations, reflecting $\mathrm{N}$ as the limiting macronutrient. Differences in Chl $a$ concentrations were 485 primarily connected to the amount of nitrate added, but were also distinctly modified by the seed community added. Treatments with different initial source water showed that the microbial seed community impacts phytoplankton succession, with the potential to influence far offshore communities in the oligotrophic subtropical gyre. The crucial period for differences in microbial community was the nutrient depleted post-bloom phase, where increased resource competition elicited divergence in biomass and post-bloom composition between replicates in unfiltered treatments. These differences in community 490 composition had an impact on nutrient drawdown. For example, silicate drawdown was higher in the unfiltered biology treatments compared to filtered organic treatments (within a given deep water). This indicates potential differences in diatom growth between replicates, likely arising from a seed population of diatoms in the unfiltered deep water added. Initial minor heterogeneity in microbial community composition, such as that observed in diatoms and Synechococcus here, may be augmented in further successions of plankton bloom developments and have consequences on overall productivity and transfer

495 of energy to higher trophic levels. Hence, nutrient upwelling promotes the occurrence of phytoplankton blooms while the upwelled community modifies these blooms.

\section{Data availability}

All data presented in this manuscript have been submitted to PANGAEA for open access archiving. A link and doi will be made available as soon as this submission is finalised. 
https://doi.org/10.5194/bg-2022-44

Preprint. Discussion started: 8 March 2022

(c) Author(s) 2022. CC BY 4.0 License.

(c) (i)

\section{Supplement link}

Detailed statistical output and other data referred to here in the text is available as Supplementary Material.

Table S1: Overview of key variables on Day 1

Table S2a: Fixed effects for final simplified model for log-transformed Chl $a$ concentrations

Table S2b: Post hoc comparisons for Chl $a$ concentrations

Table S3a: Fixed effects for final simplified model for DIN:DIP drawdown

Table S3b: Post hoc comparisons for DIN:DIP drawdown

Table S4a: Fixed effects for final simplified model for leucine aminopeptidase (LAP) activity

510 Table S4b: Post hoc comparisons for leucine aminopeptidase (LAP) activity.

Table S5a: Fixed effects for final simplified model for excess phosphate ( $\left.\mathrm{P}^{*}\right)$.

Table S5b: Post hoc output with adjusted p-values for $\mathrm{P}^{*}$ during the Bloom phase

515

Table S5c: Post hoc output with adjusted p-values for $\mathrm{P}^{*}$ during the Post-bloom phase

Figure S1: Relationship between PAR and measured Lux

Figure S2: Flow cytometry cytograms to indicate gating of different groups.

\section{Author contributions}

This study was conceived and designed by AJP, JA, KS, LTB, UR. Sampling and sample analysis were carried out by AJP,

520 EvdE, JA, JP., KS, LR, LTB, and NH. Data analysis was carried out by AJP, JA, JP, KS, LR, LTB, NH with the manuscript written by AJP with comments from all coauthors.

\section{Competing interest}

The authors declare that they have no conflict of interest.

\section{Special issue statement}

525 This manuscript is submitted to be published as a part of a Biogeosciences Special Issue "Ecological and biogeochemical functioning of the coastal upwelling system off Peru: an in situ mesocosm study".

\section{Acknowledgments}

This project was supported by the Collaborative Research Centre SFB 754 Climate-Biogeochemistry Interactions in the Tropical Ocean financed by the German Research Foundation (DFG). Additional funding was provided by the EU project

530 AQUACOSM and the Leibniz Award 2012 granted to U.R. L.R. acknowledges the support of ANID-CENTROS

REGIONALES R20F0008 and FONDECYT Project \#3170156. L.T.B acknowledges funding from the Australian Research 
https://doi.org/10.5194/bg-2022-44

Preprint. Discussion started: 8 March 2022

(c) Author(s) 2022. CC BY 4.0 License.

\section{(c) (i)}

Council (FT200100846), and KS and JP funding from the Academy of Finland (259164). J.A. was supported by a Helmholtz International Fellow Award, 2015 (Helmholtz Association, Germany). We are particularly thankful to the staff of the Instituto del Mar del Perú (IMARPE) for their support during the planning, preparation and execution of this study and to the captains and crews of BAP MORALES, IMARPE VI and BIC HUMBOLDT for support during deployment and recovery of the mesocosms and various operations during the course of this investigation. Special thanks go to the Marina de Guerra del Perú, in particular the submarine section of the Navy of Callao, and to the Dirección General de Capitanías y Guardacostas. This work is a contribution in the framework of the Cooperation agreement between the IMARPE and GEOMAR through the German Ministry for Education and Research (BMBF) project ASLAEL 12-016 and the national project Integrated

540 Study of the Upwelling System off Peru developed by the Direction of Oceanography and Climate Change of IMARPE, PPR 137 CONCYTEC. We also thank Tim Boxhammer for advice on figure preparation and design.

\section{References}

Arrigo, K. R.: Marine microorganisms and global nutrient cycles, Nature, 437(7057), 349-355, doi:10.1038/nature04159, 2005.

545 Bach, L. T., Paul, A. J., Boxhammer, T., von der Esch, E., Graco, M., Schulz, K. G., Achterberg, E., Aguayo, P., Aristegui, J., Ayon, P., Banos, I., Bernales, A., Boegeholz, A. S., Chavez, F., Chen, S.-M., Doering, K., Filella, A., Fischer, M., Grasse, P., Haunost, M., Hennke, J., Hernandez-Hernandez, N., Hopwood, M., Igarza, M., Kalter, V., Kittu, L., Kohnert, P., Ledesma, J., Lieberum, C., Lischka, S., Loescher, C., Ludwig, A., Mendoza, U., Meyer, J., Meyer, J., Minutolo, F., Ortiz Cortes, J., Piiparinen, J., Sforna, C., Spilling, K., Sanchez, S., Spisla, C., Sswat, M., Zavala Moreira, M. and Riebesell, U.:

550 Factors controlling plankton productivity, particulate matter stoichiometry, and export flux in the coastal upwelling system off Peru, Biogeosciences, 17, 4831-4852, doi:10.5194/bg-17-4831-2020, 2020.

Benner, R. and Amon, R. M. W.: The Size-Reactivity Continuum of Major Bioelements in the Ocean, Ann. Rev. Mar. Sci., 7(1), 185-205, doi:10.1146/annurev-marine-010213-135126, 2015.

Bode, A., Botas, J. A. and Fernández, E.: Nitrate storage by phytoplankton in a coastal upwelling environment, Mar. Biol., 129(3), 399-406, doi:10.1007/s002270050180, 1997.

Bruland, K. W., Rue, E. L., Smith, G. J. and DiTullio, G. R.: Iron, macronutrients and diatom blooms in the Peru upwelling regime: brown and blue waters of Peru, Mar. Chem., 93(2), 81-103, doi:10.1016/j.marchem.2004.06.011, 2005.

Carreto, J. I., Montoya, N. G., Carignan, M. O., Akselman, R., Acha, E. M. and Derisio, C.: Environmental and biological factors controlling the spring phytoplankton bloom at the Patagonian shelf-break front - Degraded fucoxanthin pigments and the importance of microzooplankton grazing, Prog. Oceanogr., 146, 1-21, doi:10.1016/j.pocean.2016.05.002, 2016.

Catalá, T. S., Martinez-Perez, A. M., Nieto-Cid, M., Alvarez, M., Otero, J., Emelianoc, M., Reche, I., Aristegui, J. and Alvarez-Salgado, X. A.: Dissolved Organic Matter (DOM) in the open Mediterranean Sea. I. Basin-wide distribution and drivers of chromophoric DOM, Prog. Oceanogr., 165, 35-51, doi:10.1016/j.pocean.2018.05.002, 2018.

Chavez, F. P. and Messié, M.: A comparison of Eastern Boundary Upwelling Ecosystems, Prog. Oceanogr., 83(1-4), 80-96, 565 doi:10.1016/j.pocean.2009.07.032, 2009.

Czerny, J., Hauss, H., Löscher, C. and Riebesell, U.: Dissolved N:P ratio changes in the eastern tropical North Atlantic: effect on phytoplankton growth and community structure, Mar. Ecol. Prog. Ser., 545, 49-62, doi:10.3354/meps11600, 2016.

Espinoza-Morriberón, D., Echevin, V., Colas, F., Tam, J., Ledesma, J., Vásquez, L. and Graco, M.: Impacts of El Niño 
https://doi.org/10.5194/bg-2022-44

Preprint. Discussion started: 8 March 2022

(c) Author(s) 2022. CC BY 4.0 License.

events on the Peruvian upwelling system productivity, J. Geophys. Res. Ocean., 122(7), 5423-5444, doi:10.1002/2016JC012439, 2017.

Falkowski, P. G., Lin, H. and Gorbunov, M. Y.: What limits photosynthetic energy conversion efficiency in nature? Lessons from the oceans, Philos. Trans. R. Soc. B Biol. Sci., 372(1730), 20160376, doi:10.1098/rstb.2016.0376, 2017.

Fawcett, S. E. and Ward, B. B.: Phytoplankton succession and nitrogen utilization during the development of an upwelling bloom, Mar. Ecol. Prog. Ser., 428, 13-31, doi:10.3354/meps09070, 2011.

575 Franz, J., Krahmann, G., Lavik, G., Grasse, P., Dittmar, T. and Riebesell, U.: Dynamics and stoichiometry of nutrients and phytoplankton in waters influenced by the oxygen minimum zone in the eastern tropical Pacific, Deep Sea Res. Part I Oceanogr. Res. Pap., 62, 20-31, doi:10.1016/j.dsr.2011.12.004, 2012.

Fuenzalida, R., Schneider, W., Garcés-Vargas, J., Bravo, L. and Lange, C.: Vertical and horizontal extension of the oxygen minimum zone in the eastern South Pacific Ocean, Deep Sea Res. Part II Top. Stud. Oceanogr., 56(16), 992-1003,

580 doi:10.1016/j.dsr2.2008.11.001, 2009.

Gorbunov, M. Y. and Falkowski, P. G.: Fluorescence induction and relaxation (FIRe) technique and instrumentation for monitoring photosynthetic processes and primary production in aquatic ecosystems, in "Photosynthesis": Fundamental Aspects to Global Perspectives, edited by D. Bruce and A. van der Est, pp. 1029-1031, Allen Press, Montreal, Canada., 2004.

585 Graco, M., Anculle, T., Aramayo, V., Bernales, A., Carhuapoma, W., Correa, D., Fernandez, J. C. E., Garcia, W., Ledesma, J., Marquina, R., Quipuzcoa, L., Romero, D., Sarmiento, M. and Solis, J.: Analysis of oceanographic and biological conditions of the coastal upwelling off Callao in contrasting periods during 2018, Bol. Inst. del Mar del Peru, 34(2), 519$543,2019$.

Green, S. A. and Blough, N. V.: Optical Absorption and Fluorescence Properties of chromophoric dissolved organic matter in natural waters, Limnol. Oceanogr., 39, 1903-1916, doi:10.4319/lo.1994.39.8.1903, 1994.

Gutiérrez, D., Akester, M. and Naranjo, L.: Productivity and Sustainable Management of the Humboldt Current Large Marine Ecosystem under climate change, Environ. Dev., 17, 126-144, doi:10.1016/j.envdev.2015.11.004, 2016.

Hauss, H., Franz, J. M. S. and Sommer, U.: Changes in N:P stoichiometry influence taxonomic composition and nutritional quality of phytoplankton in the Peruvian upwelling, J. Sea Res., 73, 74-85, doi:10.1016/j.seares.2012.06.010, 2012.

595 Helms, J. R., Stubbins, A., Ritchie, J. D., Minor, E. C., Kieber, D. J. and Mopper, K.: Absorption spectral slopes and slope ratios as indicators of molecular weight, source, and photobleaching of chromophoric dissolved organic matter, Limnol. Oceanogr., 53, 955-969, doi:10.4319/lo.2008.53.3.0955, 2008.

Humala Tasso, O., Ghezzi Solis, P., Requejo Aleman, J. C., Abregu Baez, M. del C. and Balbin Inga, N. A.: Anuario Estadistico 2013., 2015.

600 Ishikawa, A. and Furuya, K.: The role of diatom resting stages in the onset of the spring bloom in the East China Sea, Mar. Biol., 145(3), 633-639, doi:10.1007/s00227-004-1331-9, 2004.

Kämpf, J. and Chapman, P.: The Peruvian-Chilean Coastal Upwelling System, in Upwelling Systems of the World, pp. 161201, Springer International Publishing, Cham, Switzerland., 2016.

Kittu, L., Paul, A. J., Löscher, C. R., Meyer, J. and Riebesell, U.: Weak response of $\mathrm{N}_{2}$ fixation activity to low N:P 605 stoichiometry observed during a simulated upwelling event off the coast of Peru, Prep., n.d.

Kolber, Z., Zehr, J. and Falkowski, P. G.: Effects of growth irradiance and nitrogen limitation on photosynthetic energy conversion in Photosystem II, Plant Physiol., 88, 923-929, doi:10.1104/pp.88.3.923, 1988.

Krishna, S. and Schartau, M.: A data-model synthesis to explain variability in calcification observed during a $\mathrm{CO}_{2}$ perturbation mesocosm experiment, Biogeosciences, 14(7), 1857-1882, doi:10.5194/bg-14-1857-2017, 2017.

610 Lam, P., Lavik, G., Jensen, M. M., Vossenberg, J. van de, Schmid, M., Woebken, D., Gutiérrez, D., Amann, R., Jetten, M. S. 
https://doi.org/10.5194/bg-2022-44

Preprint. Discussion started: 8 March 2022

(c) Author(s) 2022. CC BY 4.0 License.

M. and Kuypers, M. M. M.: Revising the nitrogen cycle in the Peruvian oxygen minimum zone, Proc. Natl. Acad. Sci., 106(12), 4752-4757, doi:10.1073/pnas.0812444106, 2009.

Lampe, R. H., Cohen, N. R., Ellis, K. A., Bruland, K. W., Maldonado, M. T., Peterson, T. D., Till, C. P., Brzezinski, M. A., Bargu, S., Thamatrakoln, K., Kuzminov, F. I., Twining, B. S. and Marchetti, A.: Divergent gene expression among phytoplankton taxa in response to upwelling, Environ. Microbiol., 20(8), 3069-3082, doi:10.1111/1462-2920.14361, 2018.

Lampe, R. H., Wang, S., Cassar, N. and Marchetti, A.: Strategies among phytoplankton in response to alleviation of nutrient stress in a subtropical gyre, ISME J., 13(12), 2984-2997, doi:10.1038/s41396-019-0489-6, 2019.

Lassiter, A. M., Wilkerson, F. P., Dugdale, R. C. and Hogue, V. E.: Phytoplankton assemblages in the CoOP-WEST coastal upwelling area, Deep Sea Res. Part II Top. Stud. Oceanogr., 53(25), 3063-3077, doi:10.1016/j.dsr2.2006.07.013, 2006.

620 Lenth, R.: emmeans: Estimated Marginal Means, aka Least-Square Means (version 1.4.8), [online] Available from: https://cran.r-project.org/package=emmeans, 2020.

Loginova, A. N., Thomsen, S., Dengler, M., Lüdke, J. and Engel, A.: Diapycnal dissolved organic matter supply into the upper Peruvian oxycline, Biogeosciences, 16(9), 2033-2047, doi:10.5194/bg-16-2033-2019, 2019.

Lønborg, C. and Álvarez-Salgado, X. A.: Tracing dissolved organic matter cycling in the eastern boundary of the temperate

625 North Atlantic using absorption and fluorescence spectroscopy, Deep Sea Res. Part I Oceanogr. Res. Pap., 85, 35-46, doi:10.1016/j.dsr.2013.11. 002, 2014.

Maßmig, M., Lüdke, J., Krahmann, G. and Engel, A.: Bacterial degradation activity in the eastern tropical South Pacific oxygen minimum zone, Biogeosciences, 17(1), 215-230, doi:10.5194/bg-17-215-2020, 2020.

Messié, M. and Chavez, F. P.: Seasonal regulation of primary production in eastern boundary upwelling systems, Prog. Oceanogr., 134, 1-18, doi:10.1016/j.pocean.2014.10.011, 2015.

Meyer, J., Löscher, C. R., Lavik, G. and Riebesell, U.: Mechanisms of P* Reduction in the Eastern Tropical South Pacific, Front. Mar. Sci., 4, 1, doi:10.3389/fmars.2017.00001, 2017.

Morris, A. W. and Riley, J. P.: The determination of nitrate in sea water, Anal. Chim. Acta, 29, 272-279, doi:10.1016/S0003-2670(00)88614-6, 1963.

635 Morris, J. J., Lenski, R. E. and Zinser, E. R.: The Black Queen Hypothesis: Evolution of Dependencies through Adaptive Gene Loss, MBio, 3(2), e00036-12, doi:10.1128/mBio.00036-12, 2012.

Mullin, J. B. and Riley, J. P.: The colorimetric determination of silicate with special reference to sea and natural waters, Anal. Chim. Acta, 12, 162-176, doi:10.1016/S0003-2670(00)87825-3, 1955.

Oksanen, J., Blanchet, F. Guillaume Friendly, M., Kindt, R., Legendre, P., McGlinn, D., Minchin, P. R., O’Hara, R. B.,

640 Simpson, G. L., Solymos, P., H. Stevens, M. H., Szoecs, E. and Wagner, H.: vegan: Community Ecology Package (version 2.5-6), [online] Available from: https://cran.r-project.org/package=vegan, 2019.

Pennington, J. T., Mahoney, K. L., Kuwahara, V. S., Kolber, D. D., Calienes, R. and Chavez, F. P.: Primary production in the eastern tropical Pacific: A review, Prog. Oceanogr., 69(2-4), 285-317, doi:10.1016/j.pocean.2006.03.012, 2006.

Pinheiro, J., Bates, D., DebRoy, S., Sarkar, D. and R Development Core Team: nlme: Linear and Nonlinear Mixed Effects 645 Models (version 3.1-145), [online] Available from: https://cran.r-project.org/package=nlme, 2020.

R Core Team: R: A language and environment for statistical computing, [online] Available from: http://www.r-project.org/, 2020.

Rigby, S. J., Williams, R. G., Achterberg, E. P. and Tagliabue, A.: Resource Availability and Entrainment Are Driven by Offsets Between Nutriclines and Winter Mixed-Layer Depth, Global Biogeochem. Cycles, 34(7), e2019GB006497,

650 doi:10.1029/2019GB006497, 2020.

Robidart, J. C., Magasin, J. D., Shilova, I. N., Turk-Kubo, K. A., Wilson, S. T., Karl, D. M., Scholin, C. A. and Zehr, J. P.: 
https://doi.org/10.5194/bg-2022-44

Preprint. Discussion started: 8 March 2022

(c) Author(s) 2022. CC BY 4.0 License.

(c) (i)

Effects of nutrient enrichment on surface microbial community gene expression in the oligotrophic North Pacific Subtropical Gyre, ISME J., 13(2), 374-387, doi:10.1038/s41396-018-0280-0, 2019.

Schmidt, K., Schlosser, C., Atkinson, A., Fielding, S., Venables, H. J., Waluda, C. M. and Achterberg, E. P.: Zooplankton

655 Gut Passage Mobilizes Lithogenic Iron for Ocean Productivity, Curr. Biol., 26(19), 2667-2673, doi:10.1016/j.cub.2016.07.058, 2016.

Seegers, B. N., Birch, J. M., Marin III, R., Scholin, C. A., Caron, D. A., Seubert, E. L., Howard, M. D. A., Robertson, G. L. and Jones, B. H.: Subsurface seeding of surface harmful algal blooms observed through the integration of autonomous gliders, moored environmental sample processors, and satellite remote sensing in southern California, Limnol. Oceanogr.,

660 60(3), 754-764, doi:10.1002/lno.10082, 2015.

Smayda, T. J. and Trainer, V. L.: Dinoflagellate blooms in upwelling systems: Seeding, variability, and contrasts with diatom bloom behaviour, Prog. Oceanogr., 85(1), 92-107, doi:10.1016/j.pocean.2010.02.006, 2010.

Spilling, K., Camarena-Gómez, M.-T., Lipsewers, T., Martinez-Varela, A., Díaz-Rosas, F., Eronen-Rasimus, E., Silva, N., von Dassow, P. and Montecino, V.: Impacts of reduced inorganic N:P ratio on three distinct plankton communities in the

665 Humboldt upwelling system, Mar. Biol., 166(9), 114, doi:10.1007/s00227-019-3561-x, 2019.

Stauffer, B. A., Sukhatme, G. S. and Caron, D. A.: Physical and Biogeochemical Factors Driving Spatially Heterogeneous Phytoplankton Blooms in Nearshore Waters of Santa Monica Bay, USA, Estuaries and Coasts, 43(4), 909-926, doi:10.1007/s12237-020-00704-5, 2020.

Stoecker, D. K. and Gustafson, D. E.: Cell-surface proteolytic activity of photosynthetic dinoflagellates, Aquat. Microb. 670 Ecol., 30(2), 175-183, doi:10.3354/ame030175, 2003.

Stolte, W. and Riegman, R.: Effect of phytoplankton cell size on transient-state nitrate and ammonium uptake kinetics, Microbiology, 141(5), 1221-1229, doi:10.1099/13500872-141-5-1221, 1995.

Sydeman, W. J., García-Reyes, M., Schoeman, D. S., Rykaczewski, R. R., Thompson, S. A., Black, B. A. and Bograd, S. J.: Climate change and wind intensification in coastal upwelling ecosystems, Science, 345(6192), 77-80,

675 doi:10.1126/science.1251635, 2014.

Tarazona, J. and Arntz, W.: The Peruvian Coastal Upwelling System, in Coastal Marine Ecosystems of Latin America, edited by U. Seeliger and B. Kjerfve, pp. 229-244, Springer Berlin Heidelberg, Berlin, Heidelberg., 2001.

Taylor, D., Nixon, S., Granger, S. and Buckley, B.: Nutrient limitation and the eutrophication of coastal lagoons, Mar. Ecol. Prog. Ser., 127, 235-244, doi:10.3354/meps127235, 1995.

680 Weinbauer, M. G., Bonilla-Findji, O., Chan, A. M., Dolan, J. R., Short, S. M., Šimek, K., Wilhelm, S. W. and Suttle, C. A.: Synechococcus growth in the ocean may depend on the lysis of heterotrophic bacteria, J. Plankton Res., 33(10), 1465-1476, doi:10.1093/plankt/fbr041, 2011.

Welschmeyer, N. A.: Fluorometric analysis of Chlorophyll a in the presence of Chlorophyll b and pheopigments, Limnol. Oceanogr., 39(8), 1985-1992, doi:10.4319/lo.1994.39.8.1985, 1994. 